\title{
Intercritical Heat Treatment Temperature Dependence of Mechanical Properties and Corrosion Resistance of Dual Phase Steel
}

\author{
Omid Abedini ${ }^{a}$, Mohsen Behroozi ${ }^{a}$, Pirooz Marashi ${ }^{a}$, Eslam Ranjbarnodeh ${ }^{\circledR}$, Majid Pouranvari ${ }^{b}$ \\ ${ }^{a}$ Department of Mining and Metallurgical Engineering, Amirkabir University of Technology, 159163- \\ 4311, 424 Hafez Ave, Tehran, Iran \\ ${ }^{b}$ Department of Materials Science and Engineering, Sharif University of Technology, 11365-11155, \\ Azadi Ave, Tehran, Iran
}

Received: October 29, 2017; Revised: May 30, 2018; Accepted: November 08, 2018

\begin{abstract}
This study investigated the effect of intercritical heat treatment temperature on the tensile properties, work hardening and corrosion resistance of dual phase steel. Ferrite-martensite dual phase steel with different martensite volume fractions were obtained after heat treatment at different intercritical temperatures. Microstructure, mechanical properties of steel were measured and the corrosion resistance was evaluated via polarization test. Tensile strength of the specimens increased by increasing the martensite volume fraction up to $48.2 \%$. Further increase in martensite volume fraction led to decrease in tensile strength. Work hardening behavior analyzing showed that in DP steel with less than 50\% martensite volume fraction, the work hardening took place in one stage and by increasing the martensite volume fraction two-stage work hardening behavior was observed in the Holloman analysis. The results of polarization test showed that, the corrosion resistance of dual phase steel is higher than that of plain carbon steel with ferrite-pearlite microstructure.
\end{abstract}

Keywords: Dual phase steel, Intercritical heat treatment, Work hardening, Corrosion resistance.

\section{Introduction}

Dual phase (DP) steel is identified as an important class of high strength low alloy steels (HSLA). These steels have unique properties such as high tensile strength, high elongation, high strength to weight ratio, continuous yielding behavior and favorable ultimate tensile strength (UTS) to yield stress ratio ${ }^{1,2,3}$. These properties are related to microstructure of dual phase steels in which soft and ductile ferrite matrix ensures high formability; while, hard martensite phase provides strengthening effects ${ }^{1,4}$. The use of advanced high strength steels (AHSS), due to the optimal combination of these properties, in the automotive industries has increased, dramatically ${ }^{5}$. Besides the unique combination of mechanical properties, study of corrosion behavior of dual phase steels, to explore the true potential of these steels used in the automotive industries, seems to be necessary ${ }^{6}$. The easiest way to achieve special structure of dual phase steels is to perform heat treatment on low alloy steels (carbon percentages less than 0.2\%) in temperature range between $\mathrm{AC}_{1}$ and $\mathrm{AC}_{3}$ and then quenching in cool environment. As a result, ferrite-pearlite microstructure is replaced by ferrite-martensite microstructure. Since last decade, mechanical properties and corrosion behavior of dual phase steels and their relation to microstructure have been considered by many researchers ${ }^{7,8}$.

Movahed et al. ${ }^{1}$ has observed that dual phase steels with approximately equal amounts of ferrite and martensite phases

*e-mail: islam_ranjbar@yahoo.com exhibit the optimum mechanical properties in terms of tensile strength, ductility and fracture energy. Yang et al. ${ }^{7}$ studied the effect of martensite strength on the tensile strength of dual phase steels. They observed that this variation is ascending and not linear. Bag et al. ${ }^{9}$ studied a series of dual phase steels with different volume fraction of martensite (varied from 0.3 to 0.8 ) by changing the intercritical annealing temperature. They showed that DP steels with finely dispersed microstructures and 55\% martensite volume fraction had excellent mechanical properties. It is shown by Davies ${ }^{10}$ that the strength of dual phase steels is dependent on the ferrite grain size and the volume fraction of martensite and is independent of the composition and strength of the martensite. Bhagavathi et al. ${ }^{2}$ studied the mechanical properties and corrosion behavior of dual-phase steels and found that by increasing the martensite volume fraction (MFV), the UTS of dual-phase steels increased and corrosion rate of DP steel samples marginally decreased compared to that for the low alloy steel sample. Kelestemur et $a l^{11}$ showed that the corrosion rate of dual phase steel has increased with increasing the amount of martensite. Sarkar et al. ${ }^{6}$ studied the electrochemical behavior of microalloyed dual phase steels and found that an increase in martensite content and structural refinement, decreases the corrosion resistance.

In summary, there is little work on corrosion behavior and mechanical properties of dual phase steels and due to controversies in this field, further investigation is required to explore the effect of martensite volume fraction on these properties. In the present study, the SAE 1015 sheet steel was intercritically heat-treated and the effect of martensite 
volume fraction on mechanical properties and corrosion behavior of the produced DP steel was examined.

\section{Experimental Procedure}

\subsection{Material and heat treatment}

The steel used in the present study was $1.5 \mathrm{~mm}$ thick SAE 1015 ferrite- pearlite steel sheet. The chemical composition of this steel, determined using quantometric analysis technique, is shown in Table 1. quantometric analysis was done by using OSE 1000 Skyray Instrument. For the tensile testing, plane carbon steels were cut from the sheet according to the ASTM E8M.

For the present investigation, the lower and upper critical temperatures $\left(\mathrm{AC}_{1}\right.$ and $\left.\mathrm{AC}_{3}\right)$ were estimated as $742^{\circ} \mathrm{C}$ and $858^{\circ} \mathrm{C}$, respectively, by using Eqs. (1) and (2) ${ }^{12}$ :

$$
\begin{aligned}
A C_{1}\left({ }^{\circ} \mathrm{C}\right)= & 751-16.3 \mathrm{C}-27.5 \mathrm{Mn}-5.5 \mathrm{Cu}- \\
& 5.9 \mathrm{Ni}+34.9 \mathrm{Si}+12.7+3.4 \mathrm{Mo} \\
A C_{3}\left({ }^{\circ} \mathrm{C}\right)= & 881-20.6 \mathrm{C}-15 \mathrm{Mn}-26.5 \mathrm{Cu} \\
& 20.1 \mathrm{Ni}+53.1 \mathrm{Si}+12.7 \mathrm{Cr}+41.7 \mathrm{~V}
\end{aligned}
$$

All the samples were heated in intercritical temperature range (between $\mathrm{AC}_{1}$ and $\mathrm{AC}_{3}$ ) and were hold for $20 \mathrm{~min}$ in a muffle furnace followed by water quenching to produce dual phase microstructure. The heat treatment procedure which is used in this study is shown in Fig. 1. The heat

Table 1. Chemical composition of the investigated steel (wt $\%)$.

\begin{tabular}{lcccccc}
\hline $\mathrm{C}$ & $\mathrm{Mn}$ & $\mathrm{Si}$ & $\mathrm{Ni}$ & $\mathrm{Cr}$ & $\mathrm{S}$ & $\mathrm{p}$ \\
\hline 0.1 & 0.44 & 0.13 & 0.04 & 0.08 & 0.02 & 0.14
\end{tabular}

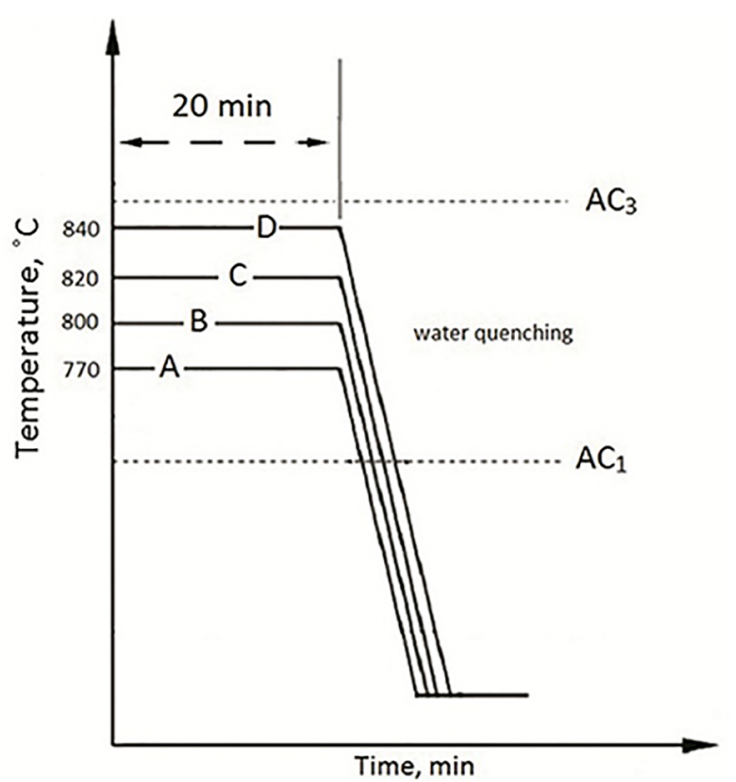

Figure 1. Schematic illustration of heat treatment cycle used in this investigation. treated samples are designated by capital letter, as shown in this figure.

\subsection{Microstructure and mechanical properties}

4 specimens of each samples were prepared to investigate the microstructure and mechanical properties of as-received and DP steel. Microstructures of the as-received and heat treated samples were observed under a light microscope following the standard metallographic polishing and etching with $2 \%$ nital solution. The volume fraction of the martensite was measured by point count technique according to ASTM E 562. Vickers hardness of the specimens was measured using $5 \mathrm{kgf}$ load with a loading duration of $10 \mathrm{~s}$ in all cases. Tensile testing was performed using an Instron 8502 machine with a cross head speed of $1 \mathrm{~mm} / \mathrm{min}$ at room temperature in accordance to ASTM E8M.

\subsection{Corrosion test}

Galvanostatic polarization technique (EG\&G 237A instrument) was used to investigate the corrosion resistance of the samples in $3.5 \% \mathrm{NaCl}$ solution at $25^{\circ} \mathrm{C}$ using a scan rate of $1 \times 10^{-3} \mathrm{~V} \mathrm{~s}^{-1}$. Before performing the corrosion test, 3 specimens of each samples were prepared and one of the surfaces of each sample was polished up to $4 / 0$ grade emery paper and then cleaned by acetone. The other surfaces of the samples were coated with an insulating lacquer. The polished surface played the role of the working electrode when immersed in the solution of the electrochemical cell comprising the platinum as counter electrode and $\mathrm{Ag}$ / $\mathrm{AgCl}$ as reference electrode. After the corrosion testing, the specimens were observed under XL300 SEM for surface degradation by corrosion.

\section{Results and Discussion}

Microstructures of the heat-treated samples are shown in Fig. 2. This figure shows the optical micrographs of A, B, C and D steels, respectively. From the micrographs shown in Fig. 2., all microstructures consisting of proeutectoid ferrite phase (light matrix) and martensite (dark phase). Fig. 3 shows the variation of martensite volume fraction (MVF) with intercritical temperature. This figure shows that, due to increase of the austenite volume fraction with increasing the intercritical temperature, the amount of martensite increases up to $74 \%$ after quenching in water.

As it is shown in Fig. 4, the hardness of heat-treated samples is influenced by variation in the intecritical temperature. It should be noted that the hardness of the as-received sample is $120 \mathrm{HV}$. By increasing temperature from $770^{\circ} \mathrm{C}$ to $840^{\circ} \mathrm{C}$, the hardness of the specimens increases from $185 \mathrm{HV}$ to 427 $\mathrm{HV}$. It can be seen that there is an increase in hardness of DP steels compared to as-received steel which is due to change in microstructure from ferrite-pearlite to ferrite-martensite. 


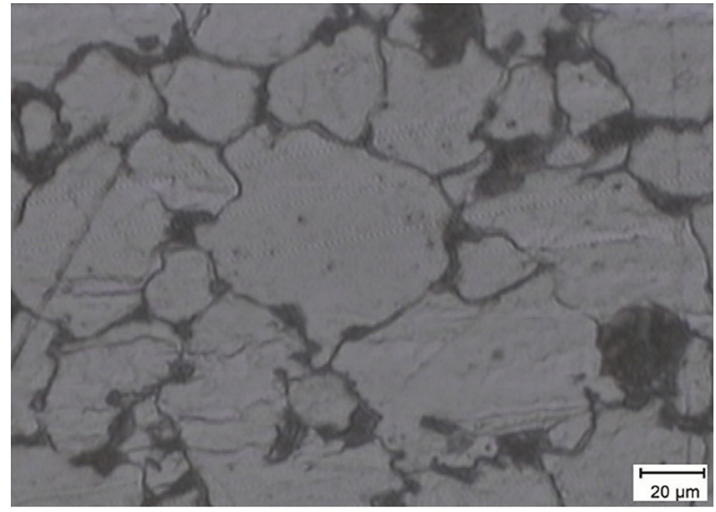

(a) $770{ }^{\circ} \mathrm{C}$

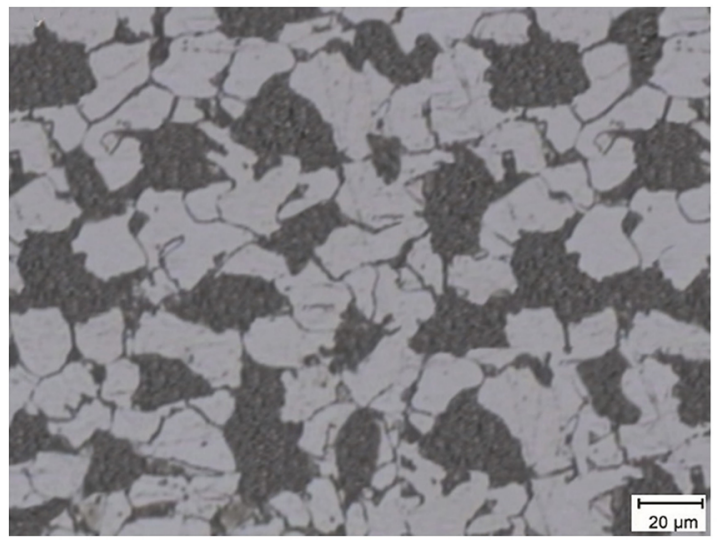

(c) $820^{\circ} \mathrm{C}$

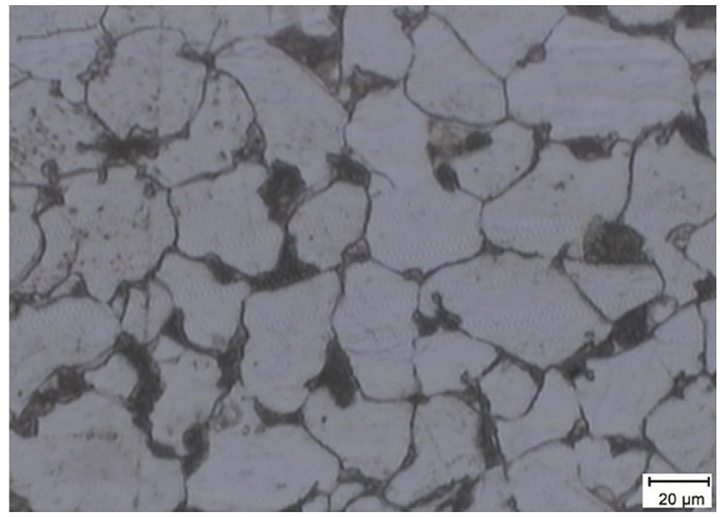

(b) $800^{\circ} \mathrm{C}$

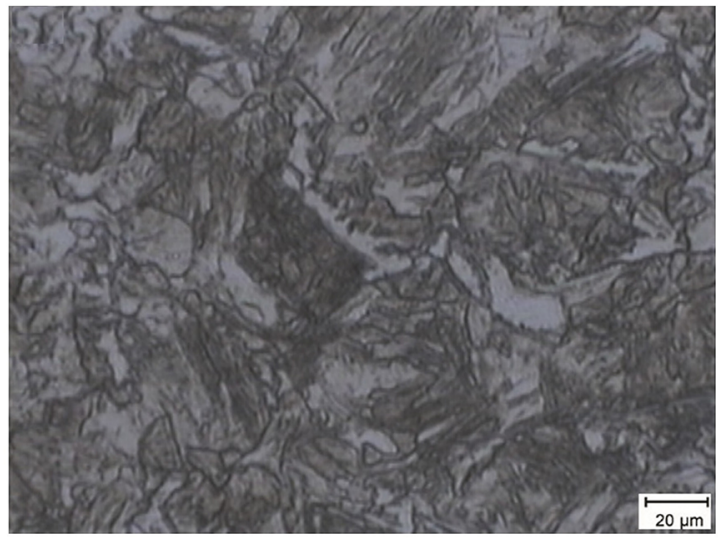

(d) $840{ }^{\circ} \mathrm{C}$

Figure 2. Optical micrographs of the heat-treated samples at various intercritical temperatures. showing light ferrite areas and dark pearlite/ martensite areas.

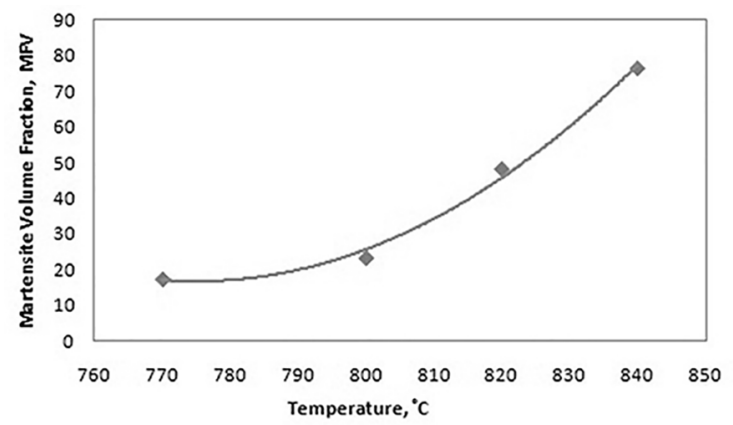

Figure 3. The variation of martensite volume fraction (MVF) as a function of intercritical temperature.

Variation of martensite volume fraction and hardness of specimens with temperature are summarized in Table 2.

\subsection{Tensile properties of DP steels}

Fig. 5a shows that the stress-strain curve of the asreceived sample has yield-point elongation and exhibits well-defined yield point while it is absent in the stress-strain

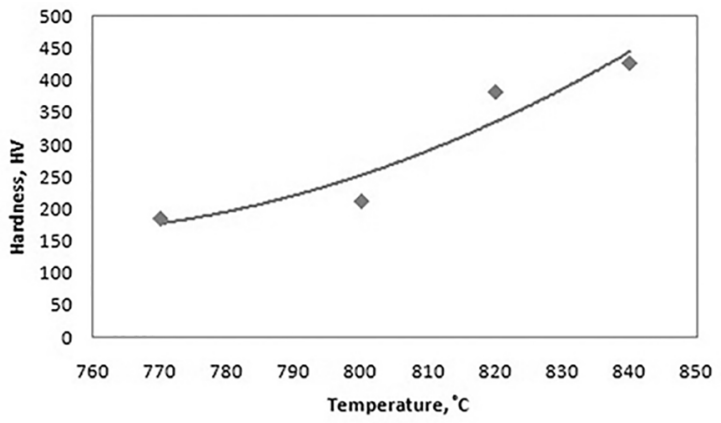

Figure 4. The variation of hardness as a function of intercritical temperature.

curves of dual phase steels in Fig. 5b. The presence of yield point phenomenon in as-received sample is related to the formation of Cottrell atmospheres ${ }^{13}$. While in DP steels, presence of martensite in the matrix of ferrite eliminates the yield point phenomenon in their stress-strain curve 10,14 . Formation of martensite from austenite, during water quenching, is associated with approximately $4 \%$ increase in 
volume. This leads to plastic deformation in the ferrite matrix and increases the density of dislocations. The high density of dislocations prevents the formation of Cottrell atmospheres, which are responsible for yield point phenomenon ${ }^{15}$. The absence of yield point phenomenon in stress-strain curves of heat treated samples confirms that a dual phase structure is successfully developed ${ }^{16}$.

Variation of UTS and \%Elongation of the DP steels with martensite volume fraction has been characterized as shown in Table 3 and Fig. 6a. The strength values of DP steels are higher than that of the as-received steel. Presence of martensite as a harder second phase in dual phase steels led to increase in the strength compared to as-received sample ${ }^{8,17}$. As can be seen in Fig. 6a, there is no proportional relationship between martensite volume fraction and ultimate tensile strength of the DP steels. By increasing the martensite volume fraction from $17 \%$ to $48.2 \%$, the UTS of DP steels increased from 643 to $1071 \mathrm{MPa}$. However, further increase in martensite volume fraction did not significantly affect UTS of DP steels. Indeed, in addition to martensite volume fraction, the hardness of the martensite phase also plays an important role in deformation behavior of the DP steels. The hardness of the martensite phase is mainly controlled by its carbon content. This parameter can be calculated by using the rule of mixtures (Eq. (3)) ${ }^{4,16}$ :

$$
C_{0}=C_{f} V_{f}+C_{m} V_{m}
$$

Where $\mathrm{C}_{0}$ is the steel mean carbon content, $\mathrm{C}_{\mathrm{f}}$ is the carbon content of ferrite and $\mathrm{C}_{\mathrm{m}}$ is the carbon content of martensite. $\mathrm{V}_{\mathrm{f}}$ and $\mathrm{V}_{\mathrm{m}}$ are also the ferrite and martensite volume fractions, respectively ${ }^{1,4,8,16}$. In this equation the

Table 2. Martensite volume fraction and hardness of specimens with temperature.

\begin{tabular}{lcc}
\hline Sample Name & $\begin{array}{c}\text { Martensite Volume } \\
\text { Fraction }\end{array}$ & Hardness(HV) \\
\hline A $\left(770^{\circ} \mathrm{C}\right)$ & 17.35 & 185 \\
$\mathrm{~B}\left(800^{\circ} \mathrm{C}\right)$ & 23.3 & 212 \\
$\mathrm{C}\left(820^{\circ} \mathrm{C}\right)$ & 48.2 & 382 \\
$\mathrm{D}\left(840^{\circ} \mathrm{C}\right)$ & 74.4 & 427 \\
\hline
\end{tabular}

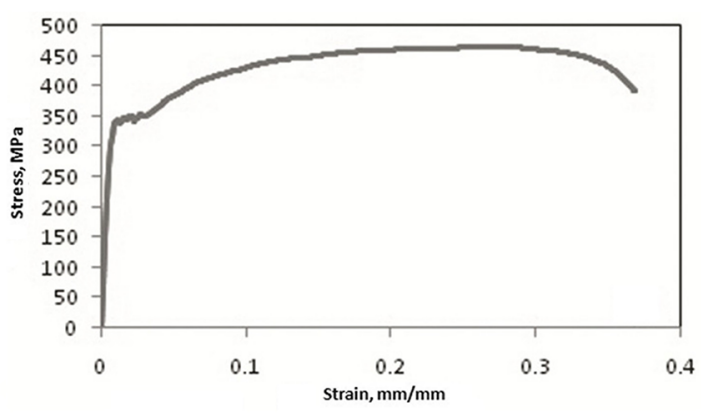

(a) As received sample carbon content is assumed to be 0.015 . It is observed from Fig. $6 \mathrm{~b}$ that as a consequence of the increase of the martensite volume fraction, the amount of carbon content of martensite decreases. Therefore, the breakdown of a proportional relationship between martensite volume fraction and tensile strength of DP steels at high martensite volume fraction can be explained by considering the combined effect of martensite volume fraction and martensite hardness. Firstly, increasing the martensite volume fraction led to increase the tensile strength of DP steels due to increasing volume fraction of harder phase. Secondly, by increasing volume fraction of martensite, the carbon content of martensite phase decreases which in turn decreases the strength of martensite.

Fig. 6a shows the correlation between martensite volume fraction and uniform elongation of the DP steels. It should be noted that the uniform elongation of the base material is $32 \%$. In sample $\mathrm{A}$, where there is $17 \%$ martensite volume fraction, the uniform elongation decreased to $16 \%$. The reduction in ductility of the DP steels compared to as-received ferrite-pearlite steel is related to the presence of hard martensite phase. Increasing in martensite volume fraction from $17 \%$ to $23 \%$ has led to further decrease in uniform elongation from $16 \%$ to $8 \%$. The presence of higher martensite volume fraction induces higher restriction on the plastic deformation of the soft ferritic matrix ${ }^{10,18,19,20,21}$. It is expected that increasing martensite volume fraction monotonically decreases the ductility of the DP steels. However, as can be seen in Fig. 6a, increasing martensite volume fraction of the heat-treated samples from 23 to $74 \%$ did not affect uniform elongation, significantly. This can be explained by reduction of carbon content of the martensite by increasing martensite volume fraction. On one hand, increasing martensite volume fraction increases the volume

Table 3. UTS and \%Elongation of the DP steels.

\begin{tabular}{lcc}
\hline Sample Name & UTS $(\mathrm{MPa})$ & \%Elongation \\
\hline $\mathrm{A}\left(770^{\circ} \mathrm{C}\right)$ & 643.6 & 15.57 \\
$\mathrm{~B}\left(800^{\circ} \mathrm{C}\right)$ & 829.5 & 8.93 \\
$\mathrm{C}\left(820^{\circ} \mathrm{C}\right)$ & 1071.8 & 9.33 \\
$\mathrm{D}\left(840^{\circ} \mathrm{C}\right)$ & 1033.5 & 10.26 \\
\hline
\end{tabular}

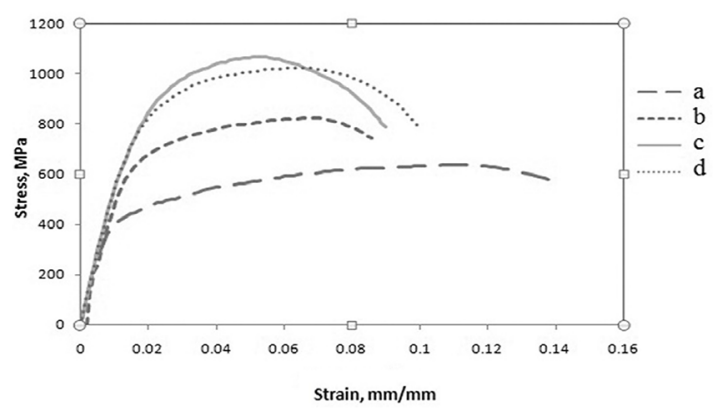

(b) Heat treated samples

Figure 5. Engineering stress-strain curves of (a) as-received and (b) heat-treated samples (a) A, (b) B, (c) C, (d) D. 


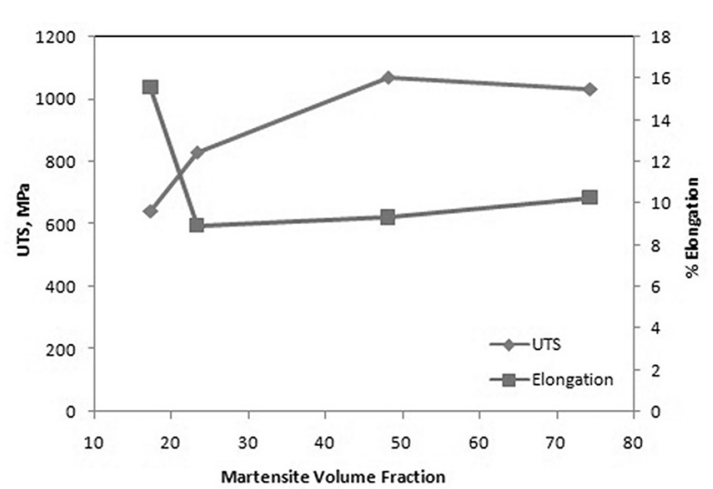

(a)

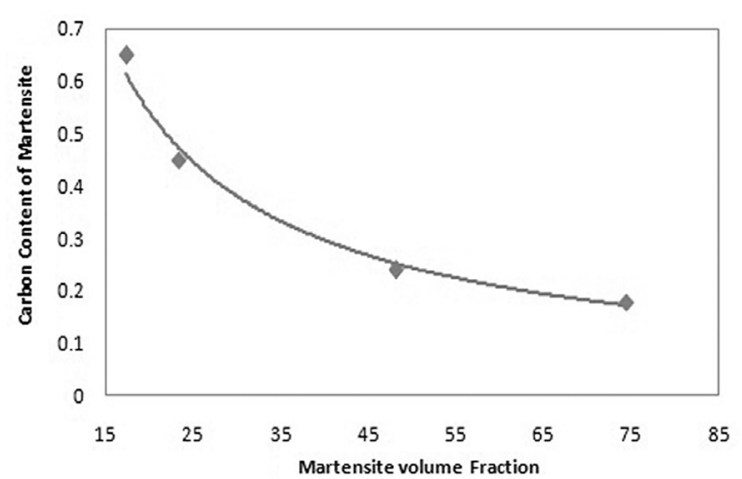

(b)

Figure 6. (a) The variation of UTS and elongation as a function of martensite volume fraction, (b) The variation of carbon content of martensite as a function of martensite volume fraction.

fraction of the hard phase in the steel and on the other hand, increasing martensite volume fraction decreases the carbon content of the martensite phase which in turn enhances the ductility of the martensite (i.e. the effect of higher martensite volume fraction on the ductility is overridden by the softness of the martensite at higher martensite volume fractions) ${ }^{22,23}$.

\subsection{Work hardening behavior of DP steels}

The flow behavior of the most metals described by the following Eq. (4). This equation is named as Hollomon equation, where ' $\mathrm{K}$ ' and ' $\mathrm{n}$ ' are constant and normally called as the strength coefficient and stain hardening exponent, respectively ${ }^{24}$.

$$
\sigma=K \varepsilon^{n}
$$

Work hardening of the metals can be good indicated by the stain herdening exponent (n). The higher value of ' $n$ ' shows the higher rate of materials work hardening. The material with a high value of ' $n$ ' is preferred for processes because of the more plastic deformation before necking starts. For this purpose, stress-strain curve in logarithmic scale should be drawn and fitting a line to these data. the slope of this line indicates the value of stain hardening exponent (n). ${ }^{25}$.

Fig. 7 shows the $\ln \sigma$-ln $\varepsilon$ diagrams for samples A, B, C and $D$. As it can be seen in this figure the variation of $\ln \sigma-\ln \varepsilon$ diagrams for DP steels with martensite volume fraction less than $50 \%$ is linear. In fact, dual phase steels with $\mathrm{V}_{\mathrm{m}}<50 \%$ have one stage work hardening behavior while the dual phase steel with $74.4 \%$ martensite volume fraction has two stage work hardening mechanism which is due to the activation of different work hardening mechanism (Table 4). The first stage can be related to ferrite plastic deformation, while both ferrite and martensite plastic deformation can lead to second stage ${ }^{27}$.

Unlike Cribb et al. ${ }^{26}$ the value of stain hardening exponent (n) increases by increasing the volume fraction of martensite. As the maximum plastic deformation is equal to work hardening power, by increasing the value of stain hardening exponent, the plastic deformation increased. So we can consider ' $n$ ' as a measure of ductility. Therefore, it is expected that by increasing the amount of martensite volume fraction, the amount of ductility and thus stain hardening exponent decrease and it is true in the case of samples $A$ and B. But this is not true in the case of samples C and D dual phase steels examined in this research. Indeed, the trend of the variation of ' $n$ ' is similar to the trend of the variation of uniform elongation with martensite volume fraction. The reason for this can be due to the difference in the strength of ferrite and martensite by increasing the martensite volume fraction ${ }^{1}$. Therefore, we can conclude that sample $\mathrm{C}$ with $48.2 \%$ martensite volume fraction has optimum mechanical properties in terms of tensile strength and ductility.

\subsection{Corrosion behavior of DP steels}

It should be noted that when the low carbon steels corrode in neutral $3.5 \% \mathrm{NaCl}$ solution, the following reactions occure on the steel surface ${ }^{6}$ :

\section{Anodic reaction: $\mathrm{Fe} \rightarrow \mathrm{Fe}^{2+}+2 e$}

\section{Cathodic reaction: $\mathrm{O}_{2}+2 \mathrm{H}_{2} \mathrm{O}+4 e \rightarrow 4 \mathrm{OH}^{-}$}

Fig. 8 indicates the potentiodynamic polarization behavior for as-received and DP samples in $3.5 \% \mathrm{NaCl}$ solution. The results of polarization studies shown in Table 5 are derived from the experimentally obtained cathodic and anodic polarization (E vs. $\log$ i) curves after using Tafel's linear extrapolation method. As it can be seen in Table 5, corrosion current density ( $\mathrm{i}_{\text {corr }}$ ) of all the DP steels is lower than that for as-received steel. As a consequence, to change in microstructure from ferrite-pearlite to ferrite-martensite, the corrosion current density $\left(\mathrm{i}_{\text {corr }}\right)$ and therefore, the corrosion rate $(\mathrm{CR})$ decrease. In DP steels the galvanic couple is formed between ferrite and martensite. The structure of 


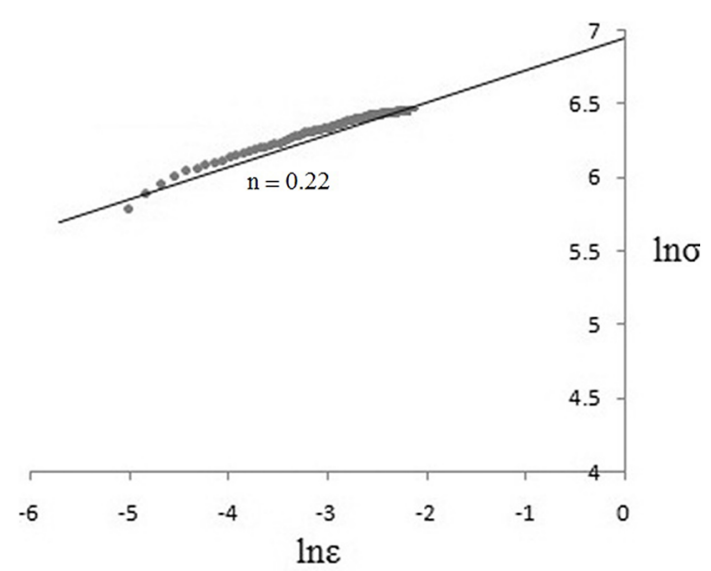

(a) sample A consist of $17.35 \mathrm{~V}_{\mathrm{m}} \%$

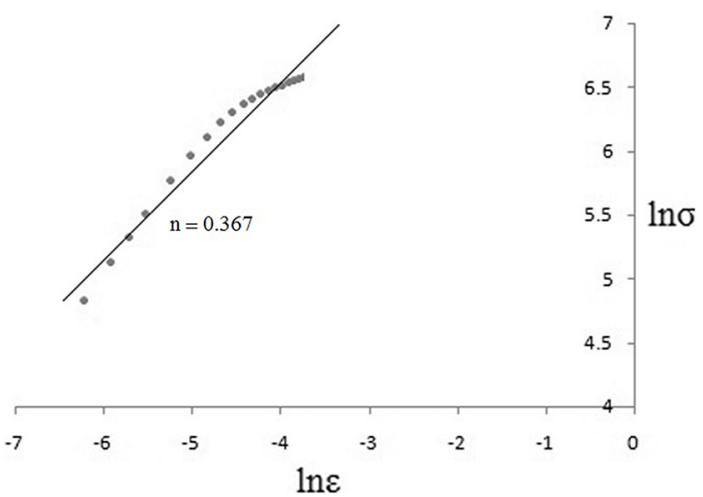

(c) Sample C with $48.2 \mathrm{~V}_{\mathrm{m}} \%$

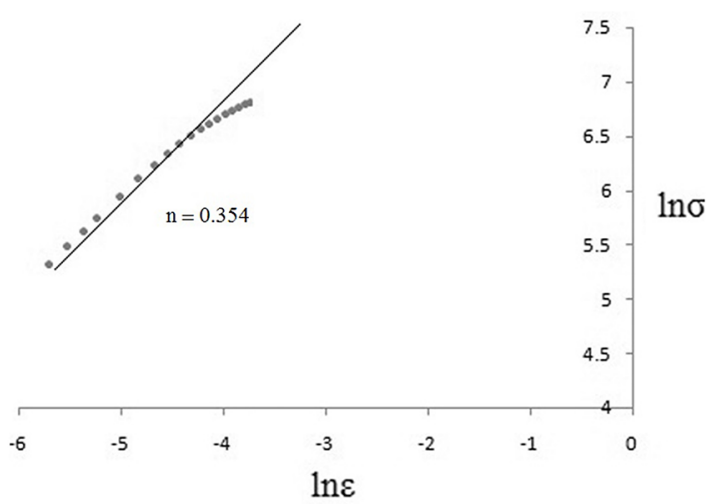

(b) Sample B consistof $23.3 \mathrm{~V}_{\mathrm{m}} \%$

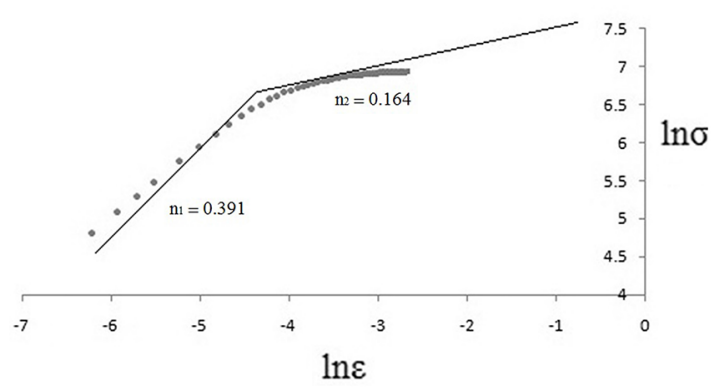

(d) sample D with $74.4 \mathrm{~V}_{\mathrm{m}} \%$

Figure 7. $\ln \sigma-\ln \varepsilon$ curves for investigated steel with different martensite volume fraction.

Table 4. Work hardening exponent for different stages for heattreated samples.

\begin{tabular}{lccc}
\hline Sample Name & $\mathrm{Vm} \%$ & Stage 1 & Stage 2 \\
\hline A & 17.35 & 0.22 & - \\
B & 23.3 & 0.354 & - \\
C & 48.2 & 0.367 & - \\
D & 74.4 & 0.391 & 0.164 \\
\hline
\end{tabular}

martensite is BCT and the structure of ferrite is BCC. Therefore, martensite phase is homogeneous with respect to composition and also structurally is closer to the matrix ferrite phase. But in as-received steel with ferrite-pearlite structure, pearlite is a mixture of ferrite and cementite lamellae, in which cementite has $6.67 \%$ carbon and an orthorhombic structure. It is relatively more inhomogeneous compositionally and structurally. In addition to number of galvanic cells across ferrite and pearlite boundaries, a large number of microgalvanic cells will be set up between lamellae of pearlite. Therefore, the galvanic couple between ferrite and martensite is weaker than that between ferrite and pearlite ${ }^{2}$. After potentiodynamic polarization testing, the as-received and heat treated samples were observed under
SEM to study the corrosion products. As it is shown in Fig. 9, and based on the above reason, the corroded surface of the as-received sample is larger than that for DP steels. Sarkar et al. attributed the increase in the corrosion rate of dual phase steel as compared to ferrite-pearlite steel ${ }^{6}$. This result is different from what is observed in the present study which can be explained as follows. Firstly, the chemical composition of steel used in this study is quite different. Secondly, island-like morphology of martensite, observed in this study, shows better corrosion resistance as compared to the network of martensite surrounding the ferrite grains in Sarkar et al. ${ }^{6}$ study. Thus, lower corrosion rate is observed for dual phase steels as compared to as-received steel. So, dual phase steels obtained by heat treating of the low carbon steel had greatly improved mechanical properties, without compromising the corrosion resistance.

Furthermore, it can be seen in Fig. 9 that the pits in sample A are smaller in size and fewer in number compared to other heat-treated samples. Fig. 10 shows the effect of martensite volume fraction on $i_{\text {corr }}$ and corrosion rate of DP steels. Due to relative change in the amount of the phase constituents, a change occurs in the ratio of cathode to anode areas. As indicated by increasing the volume fraction of martensite 


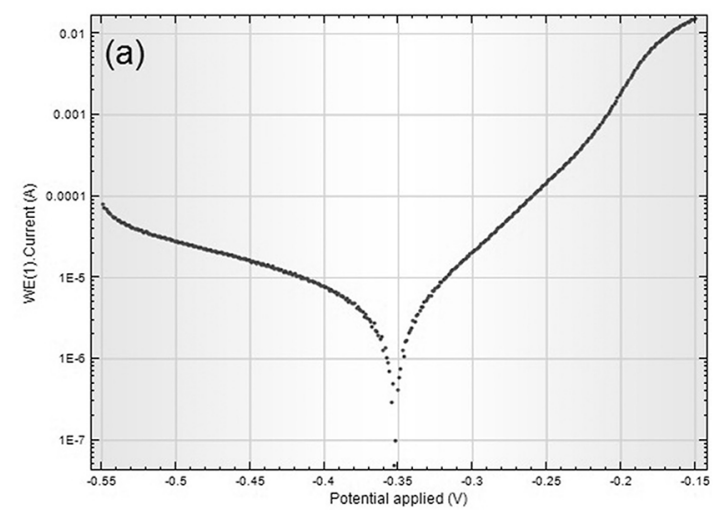

(a) sample A

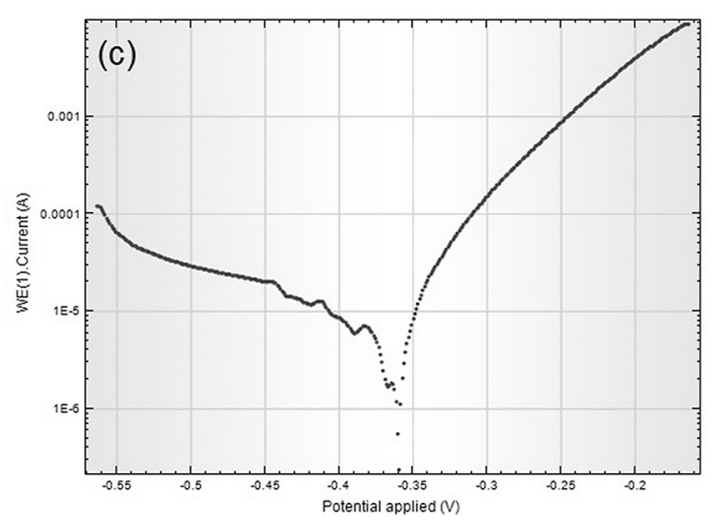

(c) sample C

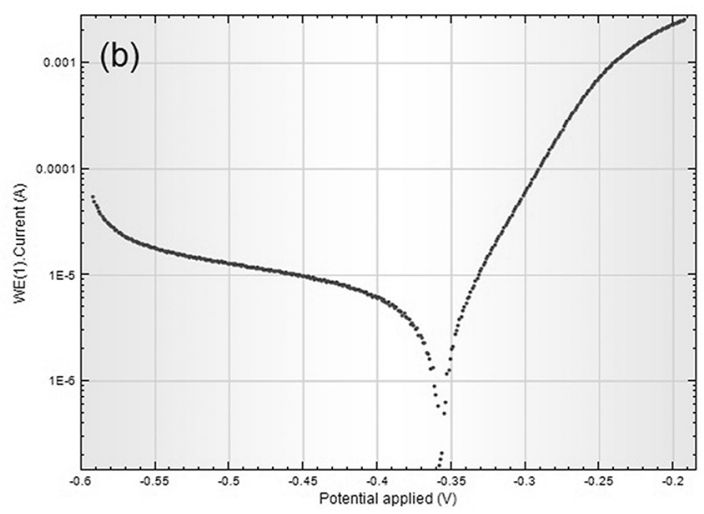

(b) sample B

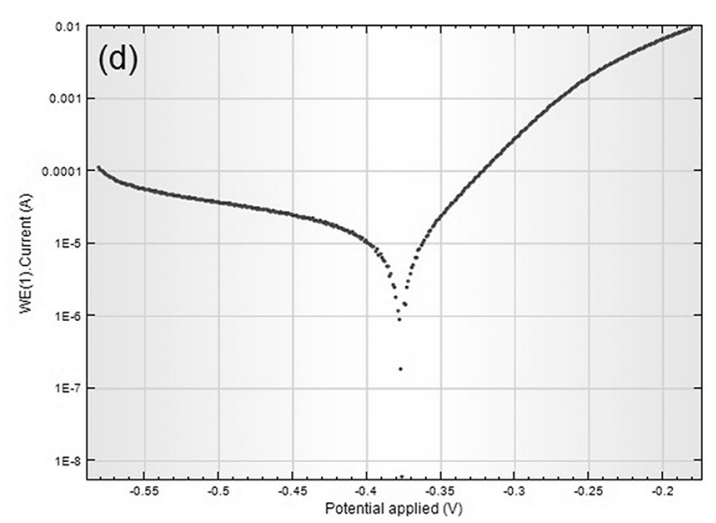

(d) sample D

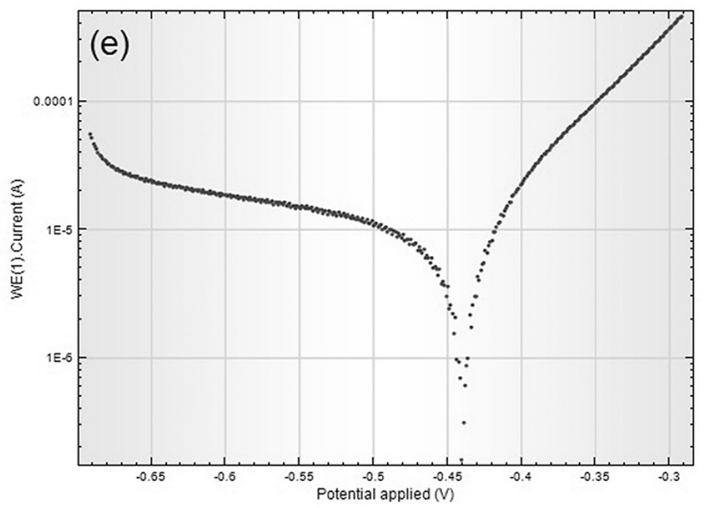

(e) Raw material

Figure 8. Potentiodynamic polarization curves.

(cathode), unfavorable area between cathode and anode increases and this leading to the higher corrosion rate of dual phase steels with higher martensite volume fraction (MFV) compared to the ones with lower volume fraction of martensite ${ }^{28}$. As a result, by increasing the amount of martensite volume fraction the severity of pitting is the highest on the surface of D sample with respect to both frequency and depth of pits.

\section{Conclusions}

In this works, ferrite-martensite dual phase steels were produced by intercritical heat treatment at various intercritical temperatures. The microstructure, tensile properties and corrosion resistance of the produced steels were investigated. The following conclusions can be drawn from this study:

- There is no proportional relationship between martensite volume fraction and ultimate tensile strength of the DP steels. By increasing the martensite 


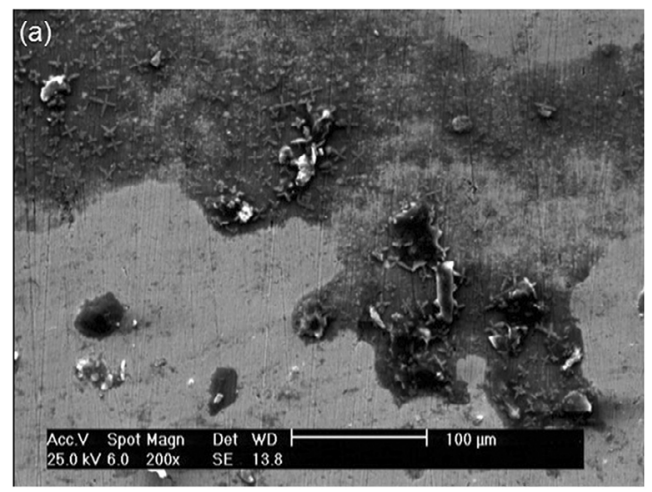

(a) As-received sample

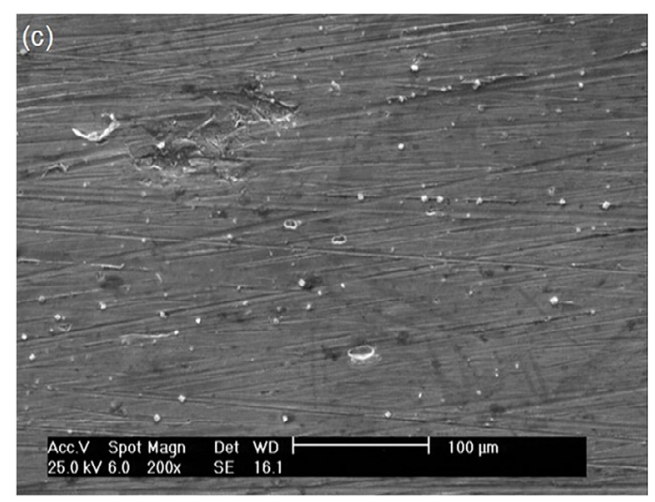

(c) Sample B

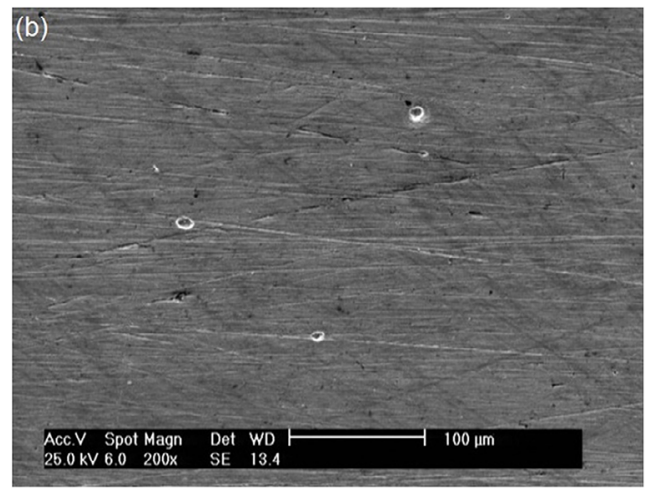

(b) Sample A

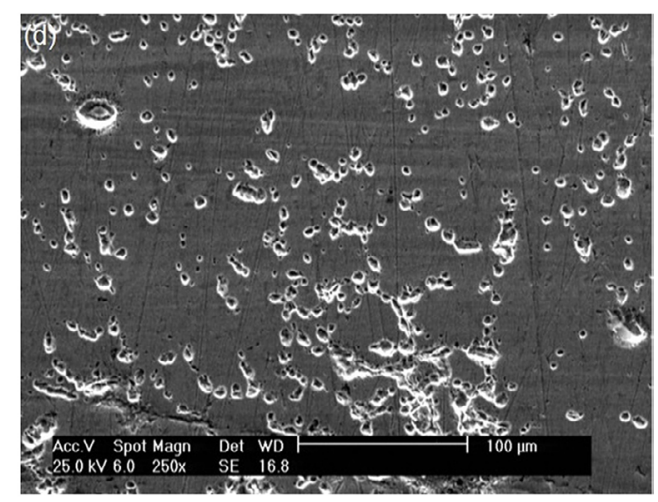

(d) Sample C

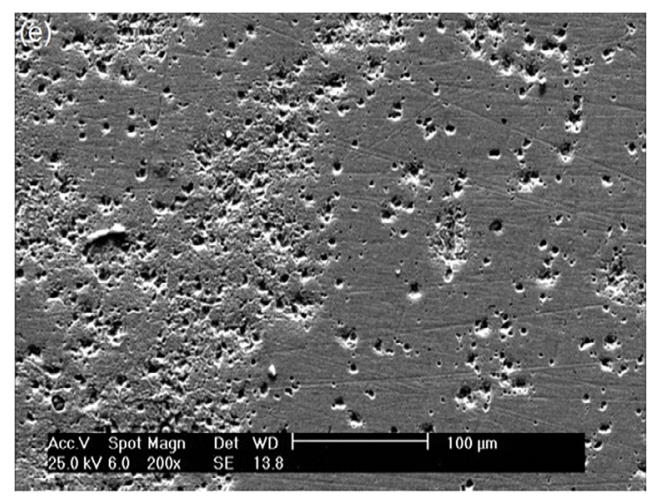

(e) Sample D

Figure 9. SEM micrographs of corroded samples after potentiodynamic polarization test.

Table 5. The results obtained from corrosion tests performed in $3.5 \% \mathrm{NaCl}$ solution.

\begin{tabular}{ccccc}
\hline $\begin{array}{c}\text { Samples } \\
\text { Name }\end{array}$ & $\begin{array}{c}\text { Pearlite/ } \\
\text { Martensite } \\
\text { Volume } \\
\text { fraction }\end{array}$ & $\begin{array}{c}\mathrm{i}_{\text {Corr }} \\
\left(\mu \mathrm{A} / \mathrm{cm}^{2}\right)\end{array}$ & $\begin{array}{c}\text { Corrosion } \\
\text { Rate } \\
(\mathrm{mm} / \text { year })\end{array}$ & $\begin{array}{c}\mathrm{E}_{\text {Corr }} \\
(\mathrm{mV})\end{array}$ \\
\hline Base & 16.8 & 13.74 & 0.159 & -0.441 \\
$\mathrm{~A}\left(770^{\circ} \mathrm{C}\right)$ & 17.35 & 4.403 & 0.051 & -0.353 \\
$\mathrm{~B}\left(800^{\circ} \mathrm{C}\right)$ & 23.3 & 5.381 & 0.062 & -0.357 \\
$\mathrm{C}\left(820^{\circ} \mathrm{C}\right)$ & 48.2 & 10.11 & 0.117 & -0.359 \\
$\mathrm{D}\left(840^{\circ} \mathrm{C}\right)$ & 74.4 & 11.22 & 0.130 & -0.377 \\
\hline
\end{tabular}

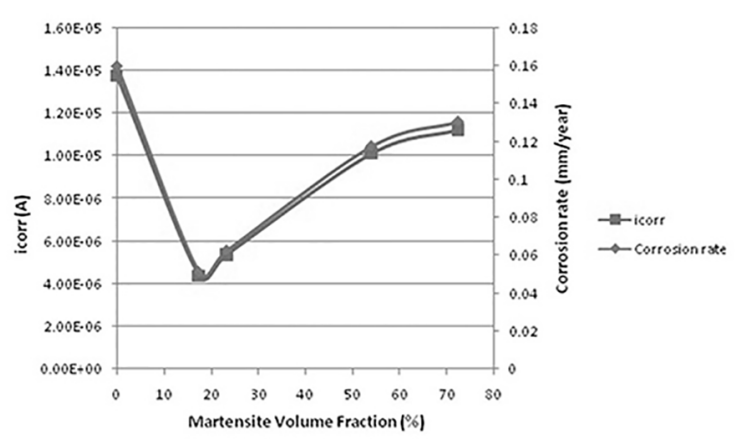

Figure 10. The variation of martensite volume fraction as a function of icorr and corrosion rate of DP steels. 
volume fraction from 17 to 48.2 , the UTS of DP steels increased from 643 to $1071 \mathrm{MPa}$. However, further increase in martensite volume fraction did not significantly affect the UTS of the DP steel.

- Uniform elongation values dropped from about $16 \%$ for sample A to about $8 \%$ for sample B by increasing the martensite volume fraction. This drop is attributed to the increase in martensite volume fraction as the harder and less ductile phase. In addition, further increase in martensite volume fraction of the steels from 23 to 74 did not affect the uniform elongation, significantly. This can be explained by reduction of carbon content of the martensite by increasing martensite volume fraction.

- The work hardening behavior of the heat treated samples with $\mathrm{V}_{\mathrm{m}}<50 \%$ is single stage. By increasing the martensite volume fraction, the work hardening capacity also increases. While For the heat treated sample containing more than 50\% martensite, two stage work hardening is observed.

- The corrosion rates obtained from potentiodynamic polarization tests showed that the corrosion rate of dual phase steels is lower than that of as-received steel. This is because of the weaker galvanic couple between ferrite and martensite compared to that between ferrite and pearlite.

- By increasing the volume fraction of martensite (cathode), unfavorable area ratio between cathode and anode increases leading to the higher corrosion rate of dual phase steels with higher volume fraction of martensite compared to the ones with lower volume fraction of martensite.

\section{References}

1. Movahed P, Kolahgar S, Marashi SPH, Pouranvari M, Parvin $\mathrm{N}$. The effect of intercritical heat treatment temperature on the tensile properties and work hardening behavior of ferrite-martensite dual phase steel sheets. Materials Science and Engineering: A. 2009;518(1-2):1-6.

2. Bhagavathi LR, Chaudhari GP, Nath SK. Mechanical and corrosion behavior of plain low carbon dual-phase steels. Materials \& Design. 2011;32(1):433-440.

3. Nikoosohbat F, Kheirandish S, Goodarzi M, Pouranvari M, Marashi SPH. Microstructure and failure behaviour of resistance spot welded DP980 dual phase steel. Materials Science and Technology. 2010;26(6):738-744.

4. Tyagi R, Nath SK, Ray S. Development of wear resistant medium carbon dual phase steels and their mechanical properties. Materials Science and Technology. 2004;20(5):645652 .

5. Tumuluru M. The Effect of Coatings on the Resistance Spot Welding Behavior of $780 \mathrm{MPa}$ Dual-Phase Steel. Welding Journal. 2007;86:161-169.
6. Sarkar PP, Kumar P, Manna MK, Chakraborti PC. Microstructural influence on the electrochemical corrosion behaviour of dual-phase steels in $3.5 \% \mathrm{NaCl}$ solution. Materials Letters. 2005;59(19-20):2488-2491.

7. Yang JR, Chen LJ. Dual ferrite-martensite treatments of a highstrength low-alloy ASTM A588 steel. Journal of Materials Science. 1991;26(4):889-898.

8. Ulu S, Kayali Y, Gunes I. Surface borided SAE 1020 steel with dual phase core microstructure. Materials Science and Technology. 2013;29(3):255-260.

9. Bag A, Ray KK, Dwarakadasa ES. Influence of martensite content and morphology on tensile and impact properties of high-martensite dual-phase steels. Metallurgical and Materials Transactions: A. 1999;30(5):1193-1202.

10. Davies RG. Influence of martensite composition and content on the properties of dual phase steels. Metallurgical Transactions A. 1978;9(5):671-679.

11. Kelestemur O, Yildiz S. Effect of various dual-phase heat treatments on the corrosion behavior of reinforcing steel used in the reinforced concrete structures. Construction and Building Materials. 2009;23(1):78-84.

12. Hayat F, Uzun H. Effect of Heat Treatment on Microstructure, Mechanical Properties and Fracture Behaviour of Ship and Dual Phase Steels. Journal of Iron and Steel Research, International. 2011;18(8):65-72.

13. Kumar A, Singh SB, Ray KK. Influence of bainite/martensitecontent on the tensile properties of low carbon dual-phase steels. Material Science and Engineering. 2008;474(1-2):270-282.

14. Sherman AM, Davies RG. The effect of martensite content on the fatigue of a dual-phase steel. International Journal of Fatigue. 1981;3(1):36-40.

15. Kot RA, Bramfitt BL, eds. Fundamentals of Dual-Phase Steels. Warrendale: TMS-AIME; 1981.

16. Fereiduni E, Ghasemi Banadkouk SS. Improvement of mechanical properties in a dual-phase ferrite-martensite AISI 4140 steel under tough-strong ferrite formation. Materials \& Design (1980-2015). 2014;56:232-240.

17. Kuziak R, Kawalla R, Waengler S. Advanced high strength steels for automotive industry. Archives of Civil and Mechanical Engineering. 2008;8(2):103-117.

18. Meyers MA, Chawla KK, Hosford WF. Mechanical Behavior of Materials. Cambridge: Cambridge University Press; 2008.

19. Garmong G, Thompson RB. A Theory for the mechanical properties of metal-matrix composites at ultimate loading. Metallurgical Transactions. 1973;4(3):863-873.

20. Marder AR. The effect of heat treatment on the properties and structure of molybdenum and vanadium dual-phase steels. Metallurgical Transactions A. 1981;12(9):1569-1579.

21. Misra SK, Nath SK. Development of dual-phase steels from plain carbon sheet steels. Zeitschrift fur Metallkunde. 1998;98(11):779-782.

22. Bayram A, Uguz A, Ula M. Effects of Microstructure and Notches on the Mechanical Properties of Dual-Phase Steels. Material Characterization. 1999;43(4):259-269. 
23. Gao B, Zhou YM, Liu JL, Shen XD, Ren ZM. Effect of water quenching process on the microstructure and magnetic property of cold rolled dual phase steel. Journal of Magnetism and Magnetic Materials. 2010;322(8):929-933.

24. Bag A, Ray KK, Dwarakadasa ES. Influence of martensite content and morphology on the toughness and fatigue behavior of high-martensite dual-phase steels. Metallurgical and Materials Transactions A. 2001;32(9):2207-2213.

25. Akbarpour MR, Ekrami A. Effect of ferrite volume fraction on work hardening behavior of high bainite dual phase (DP) steels. Materials Science and Engineering: A. 2008; 477(12):306-310.
26. Cribb WR, Rigsbee JM. Work-hardening behaviour and its relationship to the microstructure and mechanical properties of dual-phase steels. In: Morris JW, Kot RA, eds. Structure and Properties of Dual-Phase Steels: Proceedings of a Symposium. New York: AIME; 1979.

27. Lian J, Jiang Z, Liu J. Theoretical model for the tensile work hardening behaviour of dual-phase steel. Materials Science and Engineering: A. 1991;147(1):55-65.

28. Nadlene R, Esah H, Norliana S, Mohd Irwan MA. Study on the Effect of Volume Fraction of Dual Phase Steel to Corrosion Behaviour and Hardness. International Journal of Mechanical and Mechatronics Engineering. 2011;5(2):393-396. 